\title{
HALALAN TOYYIBAN: THEORY AND IMPLEMENTATION OF FOOD PRODUCTS CONSUMERS
}

\author{
Novi Yanti Sandra Dewi ${ }^{1}$ \\ Universitas Muhammadiyah Mataram, Mataram, Indonesia \\ novi.yanti@ummat.ac.id \\ Ahadiah Agustina ${ }^{2}$ \\ Universitas Muhammadiyah Mataram, Mataram, Indonesia \\ ahadiah.Agustina@ummat.ac.id
}

\begin{abstract}
For a Muslim consuming food is not only good taste, but also must meet the criteria of halalan thayyiban. Halal food is not necessarily thayyiban, because halal food at the time of processing may be given additional ingredients that are not halal. Consumers of food products should have spiritual awarenes (spiritual awareness) related to food products that they consume, especially Muslim consumers. Consuming halal food thayyiban is an order from Allah SWT, where this halal food product thayyiban has several characteristics that the food is classified as halal food, contains adequate nutrition and balanced, proportional, and safe. The purpose of this study is to examine more deeply about the theory of halalan thayyiban and the implementation of consumers of food products against the theory of halalan thayyiban, with the method used is qualitative method.
\end{abstract}

Keyword: Halalan Thayyiban, Food, Consumption 


\section{INTRODUCTION}

The Government of Indonesia has established the Institute for The Study of Food, Medicine and Cosmetics of the Indonesian Ulema Council which has the task to review and analyze the halalness of a product (Mulasakti et al., 2020). In addition, the products in circulation must be halal certified as contained in Law No. 33 of 2014 (Rasyid, 2015), (Chairunnisyah, 2017). All food on earth is basically halal for humans, but there are some types of food that are haraam because it endangers human life (Rashid, 2015), (Science, 2016). Halal means permitted as determined by Islam. Thayyib means healthy, pure, nutritious and safe (Riaz \&Chaudry, 2004). Halal terms include hygiene and hygiene in food preparation (Zainuddin \&Shariff, 2016), (Mariya Waharini \&Hakim Purwantini, 2018). Thayyib is interpreted as high quality goods and products.

Consuming halal food products thayyiban is an order of Allah SWT, as a form of the perfection of worship of a servant (Yahya et al., 2016), (Karim et al., 2020). Eating becomes a basic necessity in human life. However, it is not uncommon for people to be negligent with various things related to food consumption. Few people have spiritual awareness, they do not pay attention to what they eat and consider eating has nothing to do with spiritual values (Hygiene And Sanitation With Contamination of Fried Snacks et al., 2020), (Suteki, 2013). Therefore, there needs to be a study of the theory and implementation of food product consumers to the concept of halalan thayyiban at the Faculty of Islamic Religion, Muhammadiyah Mataram University in West Nusa Tenggara Province. This research aims to find out more in the theory and implementation of food products consumers to the concept of halalan thayyiban.

\section{REVIEW OF LITERATURE}

\section{Halalan Thayyiban Theory}

Halal means permitted as determined by Islam. Halalan in the context of food products means food that can be consumed by Islam. Thayyiban is a food that benefits people, namely healthy food, not unclean or unclean, does not cause drunkenness, does not harm health, and food and beverages are obtained in a lawful manner. Thayyib also means healthy, pure, nutritious and safe (Riaz \&Chaudry, 2004). Halal terms include hygiene hygiene in food preparation (Zainuddin \&Shariff, 2016), (Mariya Waharini \& Hakim 
Purwantini, 2018). Thayyib is interpreted as high quality goods and products (Yahya et al., 2016), (Karim et al., 2020).

Islam orders a Muslim to consume food that is considered halalan thayyiban. (Khoiruddin Syaari, 2013). This is also reinforced by the presence of the word thayyib which means good and pure. (Anas Bin Mohd Yunus et al. 2010). Halalan thayyiban means that it can be consumed related to sharia law as long as it is safe and not harmful. The concept of halalan thayyiban is also stated in hadith which means:

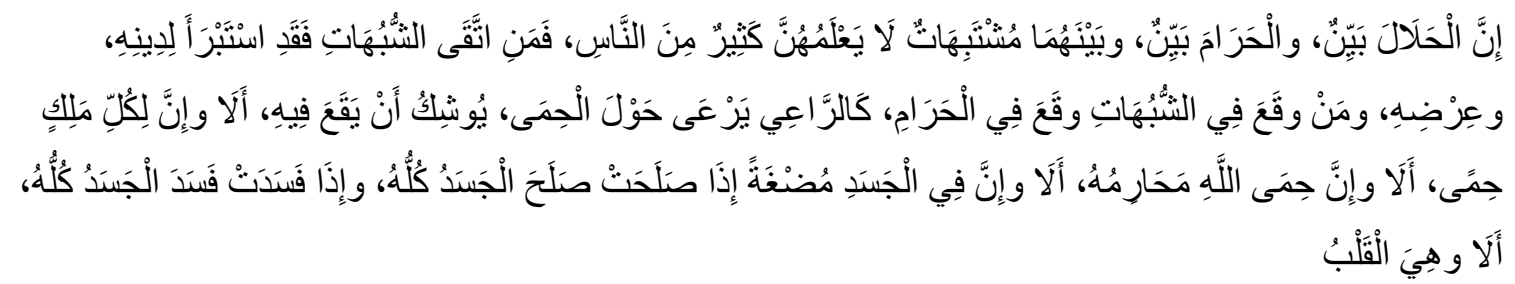

"Halal is clear and haraam is clear. Between halal and haraam there are some things that are doubtful. A lot of people don't know if it's allowed or not. Whoever forsake these dubious things to protect his religion and honor, and then he is safe. Whoever obeys these dubious things is most likely to fall into haram." (Bukhari and Muslim).

This hadeeth indicates that halal and haraam foods are clear, while foods that are not clear halal and haraam should not be consumed. Food consumed by humans is basically halal, whether the food comes from plants or animals. Food will change from halal to haram if the food is mixed unclean, intoxicating, related to the property of others or the food endangers human life. As for food that is haraam to be consumed from animals that live in two places, namely in the sea and on land.

The carcasses of fish in the sea are all halal, while the animals that live on land are all halal except land animals obtained from hunting during the hunting. The concept of halalan thayyiban is understood as a health care practice through healthy, quality and nutritious food, and the substances in the food are halal, clean, good and quality. Based on the description above, food products that can be said halalan thayyiban that must be clean, healthy and do not pose a danger to the human body. Clean food is food that is safe for consumption by a person, free from insects, not smelly and so on. Healthy food is food that does not cause disease both physically and psychically. Whereas what is meant by not causing harm is that the food does not harm human health. Food is said to be halalan 
thayyiban if the food is clean that is not in it dirt, which is sourced from halal, which does not cause disease, that does not harm, and that can provide benefits. Food can not be directly said as halal food thayyiban, but it must be seen first where the food is obtained until the food is consumed.

\section{Characteristics of Halal food products Thayyiban}

Actually all food on this earth is halal, but there are some foods that are haraam to consume because it is dangerous for humans. Therefore it is obligatory for people to know the foods that are halal and haraam, so as to consume halal food and avoid haraam foods. Food can be said halalan thayyiban if the food has met the following characteristics:

\section{Classified as halal food}

Islam allows and prohibits the consumption of food because behind the ability and prohibition there is an impact on the human body. The ability or order to consume a food is due to a positive or maslahat impact, while the prohibition of something is due to a negative impact on the body and human health. There is wisdom behind the commands and prohibitions that God has set whether we realize it or not, including in the command and prohibition of consuming a food. Avoiding to consume foods that are prohibited in Islam and only consume food that is allowed in Islam is one form of one's faith in Allah SWT. All food that is permitted by Allah SWT is good and meets human needs, while all food that is forbidden by Allah SWT because it does not meet human needs or will cause negative impacts.

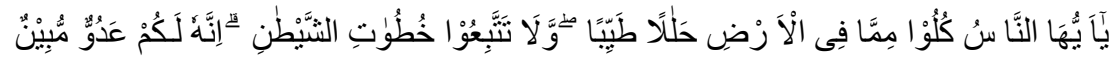

It means: "O mankind! Eat of what is lawful and good on the earth, and do not follow footsteps of Satan. Truly, satan is a clear enemy to you."

Everything that is needed by man has Allah SWT provide on this earth, but not all of them are halal for consumption. Halal food has two categories, namely good and bad, so not automatically all halal food is good. There are foods that are halal but not good for consumption. Therefore man must sort and choose the food he consumes. Therefore man must sort and choose the food he consumes. Food that is categorized as halal and good must meet two aspects. The first is from a halal source, which means that the food is obtained in a lawful manner in accordance with the provisions of Islamic law, or in other 
words that the food is not obtained in a way that is forbidden by Islamic law, such as by means of deceit, stealing, gambling or others. This is as the meaning of al-bathil in sura anNisa verse 29, which in the opinion of al-Qurthubi al-bathil means "without haq" which Ibn Kathir also said as efforts that are forbidden by sharia law', such as gambling, usury and others. Such efforts are obtained without any willingness from the parties and without reward, so such efforts are forbidden in Islam. Second, the food consumed must be good (thayyib) which means that the food contains substances needed by the body; both in terms of quantity and quality should contain balanced nutrition. Food becomes haraam to be consumed due to three things, the first is caused by its substance, the second is caused by how it is obtained, and the third is caused by the way it is processed. The explanation is as follows: a) Haram food is caused by its substances.

Some foods that are haraam to consume are carrion, blood, pork, disgusting animals, animals that live on land and in water, food and beverages that are unclean or exposed to uncleanness, food and beverages that endanger human health, food and beverages that are potentially intoxicating. The explanation is as follows: a) Carcass. Carcasses are all animals that live on land that die not because of slaughter in a syari, for example animals that die from being hit or hit by a car. The conditions of slaughter in accordance with the shar'i are the one who slaughters Muslims, reads basmalah when going to slaughter, slaughter tools or sharp slaughter knives, slaughter decides the respiratory tract, food channels, and two veins of slaughter animals; b) Blood. It is haraam to consume blood flowing from animals, whether the blood is still in liquid form or has frozen which is commonly referred to as boiling. The blood of this animal is haraam to be consumed either without any food mixture or mixed with other foodstuffs. Blood is forbidden because it is the best place for the growth of bacteria. As for the blood that is still attached to the animal slaughter that is halal, it can be consumed because this is difficult to avoid. And another food.

Based on the description above, the halal food consumed is not only influenced by the substance factor and how to get it, but also how to process it has an important role in determining the halal food thayyiban. 


\section{Contains adequate and balanced nutrition}

Food has a role in shaping the physical and mental development of humans, so religion commands all mankind to consume food that is halal again good, delicious, nutritious and beneficial for health. Consuming nutritious food that is adequate and balanced becomes a necessity to meet the needs of the body, such as meat, fish, fruits, vegetables and so on.

Thayyib food is a food that does not cause disease, so that good food is not only good in religious view but also good in medical view. This is intended for people to be healthy both physically and spiritually and have a strong mentality. One way to maintain physical health is to maintain a diet, which is to consume nutritious food. Food is not only related to human physical health and well-being, but also to spiritual health. Thayyib food is defined by nutritious foods that can support physical growth and provide quality health. The food consumed must be rich in a complete and balanced intake of nutrients, containing carbohydrates, proteins, fats, vitamins, and minerals. From the explanation above can be concluded that halal food products thayyiban must also contain adequate nutrition and balanced. This is very important to do because the benefits of food consumed are directly proportional to a person's growth.

\section{RESEARCH METHOD}

The research method used in this study is qualitative method, to investigate and understand the phenomenon that occurred. This study is going exploring involving in depth and case oriented study of the observed cases. Observations were made to bring researchers closer to the people studied or to the situation and environment also called participant observation (Wahidmurni, 2017). The method of data analysis used is descriptive data analysis method (Bita et al., 2021). This research was conducted on consumers of food products located at the Faculty of Islamic Religion Univeristas Muhammadiyah Mataram. 


\section{RESULTS AND DISCUSSION}

\section{Implementation of Halalan Thayyiban Theory of Food Products Consumers}

Understanding which person's ability to understand or know things correctly is needed, so that he can implement them in daily life. The implementation referred to here is the implementation of food products consumers to the theory of halalan thayyiban which has several characteristics, namely that the food is classified as halal food, contains adequate nutrition and balanced, proportional, and safe. The explanation is as follows: Classified as Halal Food. One of the manivestasi and investment of obedience and laughter to Allah SWT is to consume halal food and thayyib, because consuming halal food and thayyib has been ordered by Allah SWT. Halal thayyiban is not only seen from the substance, but also from the way the food is obtained, processed and used. Food that is originally halal can turn into mubah or haram if the way to consume it is not in accordance with the provisions of Allah SWT. Halal food cannot be consumed as much as desired, but as much as needed to avoid misoliness, luxury and exaggeration. Muslim consumers have a necessity to maintain the element of halalness and goodness of food in order to maintain human health, both physical and psychic. Another thing that is also a benefit of consuming halal food thayyiban is obtaining blessings.

Here are the results of interviews related to the implementation of informants to the theory of halalan thayyiban. 
Table 1

Implementation of Informant On Halalan Thayyiban Theory

\begin{tabular}{|c|l|}
\hline \multirow{2}{*}{ Informan } & \multicolumn{1}{|c|}{ Characteristics of Halal food Thayyiban } \\
\cline { 2 - 3 } & \multicolumn{1}{|c|}{ Classified as Halal Food } \\
\hline 2 & $\begin{array}{l}\text { Informants know the halal food seen from the halal label and the } \\
\text { composition on the food packaging. }\end{array}$ \\
\hline 3 & $\begin{array}{l}\text { Informants try to avoid foods that do not have halal labels to avoid } \\
\text { illegal ingredients. The informant will only buy food products that } \\
\text { have been known to be halal. }\end{array}$ \\
\hline 4 & $\begin{array}{l}\text { The informant sees first whether the food packaging has halal label or } \\
\text { not before consuming it. Informants are skeptical of the halal food if } \\
\text { there is no halal logo. }\end{array}$ \\
\hline 5 & $\begin{array}{l}\text { Informants pay attention to the halal and goodness of food consumed } \\
\text { by paying attention to the source of obtained food and halal lebel. }\end{array}$ \\
\hline 6 & $\begin{array}{l}\text { Informant observes directly the ingredients used by the seller, the } \\
\text { process of making it and also the presentation when buying or } \\
\text { consuming ready meals that do not have a halal logo such as food in } \\
\text { the cafeteria or food sold on the side of the road. }\end{array}$ \\
\hline 7 & $\begin{array}{l}\text { The informant uses information from his friends to find out the } \\
\text { halalness of a food product that does not have a halal logo. Not all food } \\
\text { can be consumed, there are foods that must be avoided, namely pork- } \\
\text { based food or disgusting food. }\end{array}$ \\
\hline $\begin{array}{l}\text { Informants know the halalness of the product by asking directly to the } \\
\text { seller or friend if the product does not have a halal logo such as food } \\
\text { sold on the side of the road. }\end{array}$ \\
\hline
\end{tabular}

Source: processed author

The results of the interview above showed that the informants implemented the theory of halalan thayyiban related to the first characteristics of halal by looking at halal lebel, composition, sources obtained food, observing directly the ingredients used and the process of making it and its presentation, information from friends, and asking directly to the seller.

Contains adequate and balanced nutrition. One way to maintain physical health is to consume nutritious and balanced food. Nutritious food can support physical growth and provide quality health. The food consumed must be rich in a complete and balanced intake of nutrients, containing carbohydrates, proteins, fats, vitamins, and minerals. Here are the results of interviews related to the implementation of informants to the theory of halalan thayyiban about nutritious food is sufficient and balanced. 
Table 2

Implementation of Informants Against Halalan Thayyiban Theory of Nutritious Food Is Sufficient and Balanced

\begin{tabular}{|c|l|}
\hline \multirow{2}{*}{ Informan } & \multicolumn{1}{|c|}{ Characteristics of Halal food Thayyiban } \\
\cline { 2 - 3 } & \multicolumn{1}{|c|}{ Contains Adequate and Balanced Nutrition } \\
\hline 1 & $\begin{array}{l}\text { The informant chooses the food consumed, taking into account the } \\
\text { ingredients in the food if the food is sold on the side of the road }\end{array}$ \\
\hline 2 & Informant pays attention to the composition of food in the packaging \\
\hline 3 & Informant tries to consume four healthy five perfect foods \\
\hline 4 & Informants sort and choose foods that nourish the body \\
\hline 5 & Informant buys various variants of food needed by the body \\
\hline 7 & Informant sees nutritional value information on the packaging \\
\hline 7 & $\begin{array}{l}\text { Informan budgets certain expenses to consume nutritious food } \\
\text { adequately and balanced }\end{array}$ \\
\hline
\end{tabular}

Source: processed author

From the results of the interview above can be known that the informant implements the characteristics of halal food thayyiban which is a food that contains adequate nutrition and balanced, by looking at nutritional information, ingredients in the food, composition and budgeting expenditure to buy nutritious food.

\section{CONCLUSION}

Consumers of food products in the Faculty of Islamic Religion, Muhammadiyah University of Mataram have implemented the theory of halalan thayyiban food products, taking into account the halalness of food products, nutritional content and balance, proportion and safety of food products.

Implementation of halal theory thayyiban food products related to halal food products is realized by checking halal lebel on the packaging, and if the food product is not halal label then ask a friend or ask directly to the seller about the halalness of the food product.

Implementation of adequate and balanced nutritional content characteristics is realized by paying attention to the ingredients in the food, the composition of the food in the packaging, consuming four healthy five perfect foods, sorting and choosing foods that are healthy to the body, buying various variants of food needed by the body, buy various variants of food needed by the body, see the nutritional value information in the packaging, and budget certain expenditures to consume nutritious food adequately and balanced. 
Implementation of proportional characteristics is realized by consuming foods that suit the needs and conditions of the body, consuming healthy foods, although some do not or do not pay attention to the needs of the body by consuming foods that he thinks are delicious and existing foods.

Implementation of safe characteristics in food products is realized by consuming foods that do not harm the health of the body, consuming foods that can provide benefits for human health that will make the soul, avoid foods that can cause disease and that can aggravate disease, see the feasibility of food products, pay attention to the composition of food, avoid preserved foods, and see the expiration date of food that is on the packaging.

\section{REFERENCES}

Ali, M. (2016). Concept of Halal Food in Sharia Review and Product Responsibility for Halal Industry Manufacturers. AHKAM: Journal of Sharia Sciences, 16(2), 291306. https://doi.org/10.15408/ajis.v16i2.4459

Chairunnisyah, S. (2017). The Role of the Indonesian Ulema Council in Issuing Halal Certificates on Food Products and Cosmetics. EduTech: Journal of Education and Social Sciences, 3(2), 64-75.

Hygiene And Sanitation With Contamination of Fried Snacks, H. D., Novelia Department of Public Health, G., \& Public Health, F. (2020). The Association of Hygiene Fried Snacks at Elementary Schools Cafeteria.

In The Journal of Environmental Health Halu Oleo Karim, R. A., Mahmud, N., Marmaya, N. H., \& Hasan, H. F. A. (2020). The Use of Total Quality Management Practices for Halalan Toyyiban of Halal Food Products: Exploratory Factor Analysis.

Mulasakti, G. P., Studi, P., Islam, E., \& Diponegoro, U. (2020). Determining Factors of Interest in Buying Imported Food and Beverage Products Labeled Halal. Journal of Islamic Economics Scientific Journal of Islamic Economics, 6(02), 2020, 294-303.

Palinkas, L. A., Horwitz, S.M., Green, C. A., Wisdom, J. P., Duan, N., \& Hoagwood, K. (2015). Purposeful Sampling for Qualitative Data Collection and Analysis in Mixed Method Implementation Research.

Rasyid, A. (2019). Dynamics of Halal Certification Implementation in Food and Beverage Products In Medan, Sibolga And Padangsidimpuan. MIQOT: Journal of Islamic Sciences, 43(2), 167. https://doi.org/10.30821/miqot.v43i2.640

Rasyid, M. H. (2015). The Role of Halal Product Guarantee Law in Ensuring Halal Food and Beverages. Sharia Journal 3, November, 4-27.

Ropianto, M. (2016). Pemahaman Penggunaan Unified Modelling Language. Jt-Ibsi. 
Sains, U. (2016). Counselling The Stressed For Psychological Wellbeing. Journal of Islamic Social Sciences and Humanities, 8, 45-61.

Shafiee, N. F., Karim, M. S. A., Razali, A. B., \& Abidin, U. F. U. Z. (2018). Halalan Toyyiban Understanding: A Case of Muslim Street Food Vendors in Shah Alam. Journal of Islamic, Social, Economics and Development, 3(15).

Suteki, M. (2013). Pelaksanaan Layanan Khusus Kantin Di SMP Negeri 1 Diwek Jombang. Inspirasi Manajemen Pendidikan 1(1).

Yahya, H., Samicho, Z., Firdaus, A., \& Nurul, M. (2016). A Review on Application of Halalan-Toyyiban Risk Management Plan (HTRMP) and Frozen Food Chain during Warehousing Activities for Maintaining Halal, Safety, and Quality. Journal of Applied Enviromental and Biological Sciences, 6(11), 96-102.

Yusuf, H. (2016). Understanding Human Resources.

Zainuddin, A., \& Shariff, S. M. (2016). Preferences for Halalan Toyyiban Retail Supply Chain Certification: A Case of Hypermarket. Procedia Economics and Finance, 37, 405-411. https://doi.org/10.1016/s2212-5671(16)30144-7 